\title{
The Effects of the Management Strategies on Spruce Bark Beetles Populations (Ips typographus and Pityogenes chalcographus), in Apuseni Natural Park, Romania
}

\author{
Ciprian George Fora ${ }^{1, *}$ and Adalbert Balog ${ }^{2, *(\mathbb{D}}$ \\ 1 Faculty of Horticulture and Forestry, Banat's University of Agricultural Sciences and Veterinary Medicine \\ "King Michael I of Romania" from Timișoara, Calea Aradului 119, 300645 Timișoara, Romania \\ 2 Department of Horticulture, Faculty of Technical and Human Sciences, Sapientia Hungarian University of \\ Transylvania, Aleea Sighișoarei 1C, 530104 Târgu Mureș/Corunca, Romania \\ * Correspondence: ciprian.fora@usab-tm.ro (C.G.F.); adalbert.balog@ms.sapientia.ro (A.B.)
}

Citation: Fora, C.G.; Balog, A. The Effects of the Management Strategies on Spruce Bark Beetles Populations (Ips typographus and Pityogenes chalcographus), in Apuseni Natural Park, Romania. Forests 2021, 12, 760 https://doi.org/10.3390/f12060760

Academic Editors: Young-Seuk Park and Won Il Choi

Received: 19 April 2021

Accepted: 7 June 2021

Published: 9 June 2021

Publisher's Note: MDPI stays neutral with regard to jurisdictional claims in published maps and institutional affiliations.

Copyright: (c) 2021 by the authors. Licensee MDPI, Basel, Switzerland. This article is an open access article distributed under the terms and conditions of the Creative Commons Attribution (CC BY) license (https:// creativecommons.org/licenses/by/ $4.0 /)$.

\begin{abstract}
The population densities of I. typographus and P. chalcographus inside the Carpathian Mountains increasing mostly because of the non-synchronized and divers management strategies. The growing loss of trees from one year to another indicates assessment to determine the influence of the current management practices (or the absence of such) on bark beetle densities. A comprehensive tree-year assessment were made inside the Apuseni Natural Park, with a surface of 75,784 ha, to assess the population density of bark beetles. High abundance of both species were detected from one year to another, both in managed and unmanaged forests, the latter explained by the presence of scattered wind falling trees which represent favorable places for oviposition. General linear modelling revealed that the effect of environmental variables (forest mean age, forest density, altitude and slope) on I. typographus density were only significant under management systems, and only forest age has significantly negative effect on bark beetles densities. Overall, we conclude that there is little difference in population between non-intervention and intervention areas and even over a relatively short period of time (2011-2013), the population of both species expanded, and new uninfected habitats were infected both in unmanaged and managed forests, therefore a synchronized management system has to be developed. Climate variables as temperature and precipitations has more significant effects on population density than management.
\end{abstract}

Keywords: conservation areas; management systems; spruce forest; climate change; population density

\section{Introduction}

Bark beetles (Coleoptera: Curculionidae: Scolytinae), are the most important pests of coniferous trees [1]. Of those belonging to the genus Ips, Ips typographus is the most destructive species, damaging spruce forests across Eurasia [2], and causing economicallysignificant attacks in spruce forests [3-5]. In addition, beetles of the genus Pityogenes can also be of considerable economic importance. For example, Pityogenes chalcographus is one of the most abundant bark beetle species in Europe and can be detected widely in Picea (Picea abies (L.) H. Karst) forests, ranging from Scandinavia to the Balkans [6]. Damaged produced by this latter species was found to increase from one year to another throughout Eurasia [7], with more severe damage to Picea trees being widely reported [8,9]. Damage is frequently detected in combination with that of I. typographus (Linnaeus, 1758), cases when the two species occur together producing more severe losses that when found alone, as frequently described in the literature, even early papers [10]. Several studies have reported that $P$. chalcographus prefers young trees, with enhanced physiological demands and thus more sensitive to attack [11-13], with the highest density of infestation detected in trees between $25-45$ years [14]. 
Economic thresholds (the individual number which requires already intervention to protect trees) for I. typographus were detected at different levels, and were reported at 8000 individuals/trap/year by Faccoli \& Stergulc (2004), with a strong correlation found between individual numbers and tree numbers. Other papers have reported 10,000 individuals/trap/year [15], or sometimes even as high as 15,000 individuals/trap/year [16]. With $P$. chalcographus, economic thresholds were reported as 20,000 up to 60,000 individuals/trap/year [17]. In Romania, 3000 individuals/trap/year have been reported for I. typographus and 30,000 individuals/trap/year for P. chalcographus [18]. While high variations in economic thresholds can be detected, the effect of management, which usually follows the practices that dead trees and wood residuals are left after harvest for a longer time near healthy growing trees, are rarely considered. Previous related researches have mentioned that tree mortality was most strongly determined by standing trees killed by bark beetles in the previous year and left in the forest, followed by wind-felled trees. Precise and timely removal of infested trees is a suitable method to control bark beetle infestation [19]. Another study also reported that the application of selective control methods reduced mainly the populations of I. typographus (results detected by using pheromone traps), and no effect on P. chalcographus were detected. This is because a large volume of fresh logging residues, mainly tree tops and branches remaining in stands, offer excellent breeding conditions for $P$. chalcographus. It was also reported that the fast increase of this species population seems to be a consequence of recent human errors concerning insect control and forest management [14].

Overall, it appears that the increasing densities of these insects should be further investigated and management practices compared in other regions (i.e., Carpathian Mountains) with large protected forest areas. Also, the effect of climate change has to be considered in such assessments. Therefore in the present study, our main goal was to assess the population density of I. typographus and P. chalcographus inside the Natural Park Apuseni, Romania and to determine whether or not current management practice ('non-intervention' and 'intervention' strategies) have a marked effect on bark beetles densities.

\section{Materials and Methods}

\subsection{Study Area}

The Apuseni Natural Park (Western Carpathian Mountains, Central Europe, $\left(46.604^{\circ} \mathrm{N}\right.$, $22.810^{\circ} \mathrm{E}$ ), with a surface of $75,784 \mathrm{ha}$, is one of the most important protected area from Western Romanian Carpathians. Covered mainly with forests, about $75 \%$, with a special karst heritage, the natural park of the Bihor Mountains is included in category V IUCNProtected Landscape (Figure S1). The main trees species which compose the forests are spruce, Picea spp. (70\%), fir, Abies spp. (2\%) and beech, Fagus sylvatica (27\%). Other resinous species like pine and larch and few species of deciduous trees like ash, sessile oak, sycamore, birch and elm, can be found.

\subsection{Forests Status and Management}

In the past, the forests of Apuseni Mountains, composed mainly by European spruce, were owned and managed, in the respect of Romanian forest protection standards, by three state forest directorates: Alba, Bihor and Cluj (common named with counties). Valuable forests of spruce or spruce mixed with beech and fir were included in conservation areas ( $20 \%$ from total forests surfaces) and the remaining $80 \%$ of spruce mixed with beech and fir in buffer areas in 2004, during this time the protected natural park was established. All over of these surfaces, the internal zoning of the park imposed including of the forest stands in conservation areas (unmanaged forests) and buffer areas (managed forests). In unmanaged forest, no interventions are allowed. Just in case of major disturbances created by abiotic and/or biotic factors, in unmanaged forests interventions are allowed after a long and hard procedure, which take years (elimination of dead trees as example). Parallel, in the last three decades, a complex and yet un-finalized process of restitution of the forests takes place. Either unmanaged or managed stands changed properties, from the state to the private 
entities or private persons. These created difficulties to apply all forest protection measures in managed forests and to respect non-intervention in unmanaged forests. In August 2006, a highly destructive storm affected the forests in both conservation and buffer areas of the park, resulting in a huge quantity of wind felled trees. In every year since then, interventions have been performed in both areas to assess natural calamities and involving delineation of the protected areas by special minimally-planted buffer zones. However, starting in 2010, no more intervention was allowed in forests belonging to the conservation areas. In this context the population densities of I. typographus and P. chalcographus inside the Apuseni Natural Park, increased, especially after wind throw from 2006 which affect more than 200,000 cubic meter of spruce trees in unmanaged and managed forests and as an effect of climate change.

\subsection{Site Selection and Environmental Conditions}

Selection of the research sites (Table S1), were the following: the forests are included in conservation areas (unmanaged forests), with a non-intervention strategy (i.e., no dead trees were removed from the forest or no other management activity were followed). In buffer areas (managed forests), with an intervention strategy (i.e., all dead trees investigated and removed from the forests, with pheromone traps used to assess bark beetle densities, with trap trees to decrease the bark beetles population level. All other forest protection measures applied); the forests covering a range of stand conditions; the existence of minimum three spruce trees per site colonized by the bark beetles; the forests are accessible.

In total, 48 permanent research sites have been established (Figure 1) inside the Forest Directorates/counties (Alba-site A, Bihor-site B and Cluj-site C). From these, 24 infested by I. typographus (16 unmanaged forests and 8 managed forests) and 24 infested by $P$. chalcographus (17 unmanaged forests and 7 managed forests) were established (Figure S1). We used site as differences (independent variables) because sites located in different counties have different administrative strategies with independent regime. Forest management reorganization is under progress in Romania and not even the property rights were clarified yet.
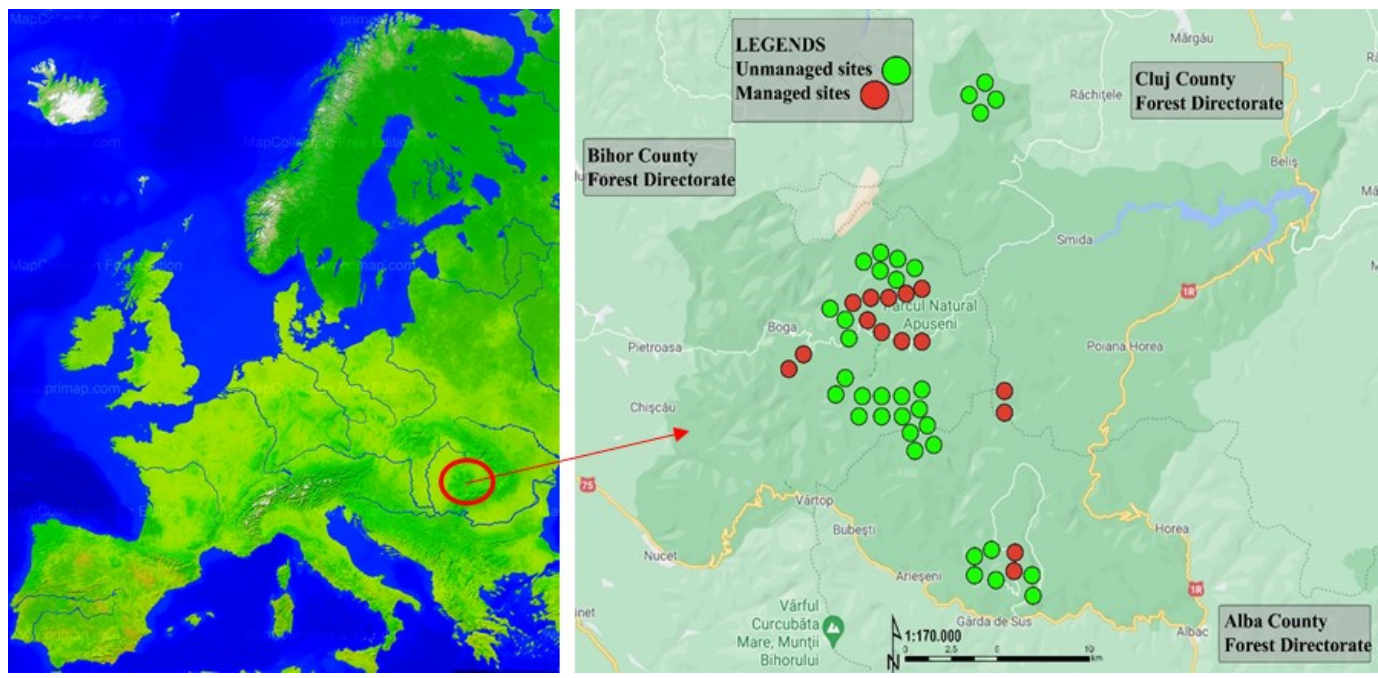

Figure 1. Map of the areas investigated in the Apuseni Natural Park ( $\left.46.604^{\circ} \mathrm{N}, 22.810^{\circ} \mathrm{E}\right)$, Romania. Unmanaged sites are marked with green, managed sites with red.

Of these sites, in $80 \%$ of the research forest stands, spruce comprised between 90 to $100 \%$ of the trees, whilst $75 \%$ had a mean age between 60 to 120 years old, $28 \% 120$ to 170 years old, and just $8 \% 20$ to 60 years old. The altitude of the sites was between 800 to $1500 \mathrm{~m}$ a.s.l. The climate characterizing the whole area may be described as temperate-continental, with multiannual mean temperature of $4.6^{\circ} \mathrm{C}$ and mean precipitation of $1600 \mathrm{~mm}$ per year. Climate conditions during the assessment period are presented in Figure 2. During the 
research, no significant gale conditions were registered; however, downwind trees were observed scattered around the forests, whilst dying trees caused by the bark beetles attack were also seen to be present and similarly scattered in the forest.

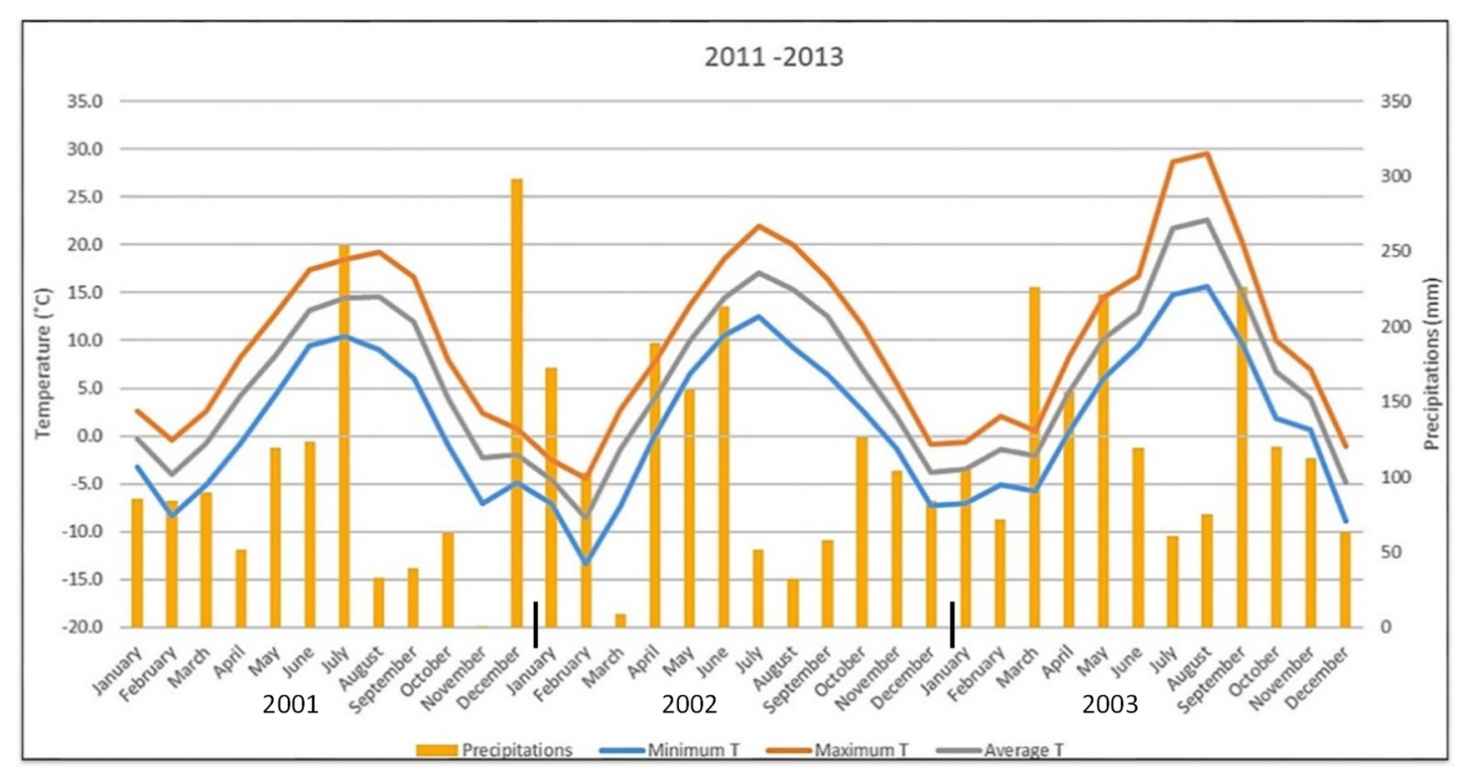

Figure 2. Temperature and precipitation values in the target areas between 2011-3013.

\subsection{Data Collection}

In each site, Theysohn slot traps baited with synthetic pheromones were used. Placement of the traps was performed as much as possible in sunshine, at $15-20 \mathrm{~m}$ distance by the spruce trees stands, and at $1.3 \mathrm{~m}$ above the ground. The synthetic pheromone used for I. typographus was S-cis verbenol 3.3\%, namely (1S, 2S)-4,6,6-trimethylbicyclo (3.1.1) hept-3-en-2-ol (IT-Ecolure Tubus Mega) and for P. chalcographus, Chalcogran 4\%, namely 2-ethyl-1,6 dioxaspiro $(4,4)$ nonane (PC-Ecolure Tubus Mega). The pheromones were active for 22 weeks according to the manufacture's advice and cover the period of spring and summer beetle flights. The level of pheromone in the tubes was simultaneously checked with that of the beetle collection. The traps were active between the end of April until the end of September of each sampling year. Trapped beetles were collected weekly in plastic boxes, labeled according to the particular trap and date of collection, and stored in the fridge at $-20^{\circ} \mathrm{C}$. Periodically, the boxes were transported from the Forest Entomology Laboratory to the University of Timisoara for analysis. Beetles from each sample were physically counted up to 500 individuals, whereafter bigger samples were measured volumetrically.

\subsection{Data Analysis}

Insect density values for each sampling period, location and year were averaged between the same traps. Thereafter, all data were $\log 10$ transformed to reduce the influence of high values (by adding 1 to each value and then $\log 10$ transforming it). This was followed by a normality test and homogeneity of variance. As all data were normally distributed, one-way ANOVA followed by Tukey HSD test were used to compare abundances between sites and treatments. Each year was considered separately in this analysis. Statistically significant differences were considered at a level of $p<0.05$. Next, all data were again compared, this time as each year, site and treatment using one-way ANOVA followed by Tukey HSD test $(p<0.05$ level). In the following analyses, heat-map matrices were constructed to compare abundances between sites, treatments and flying periods for each year and species. In this approach, matrices blue colors represents low abundances, red colours high abundances. General linear model (GLM) was used to test the effect of 
environmental variables (forest age, forest density, altitude and slope) on beetle density using forest mean age, forest density, altitude and slope as independent variable, and each species group as a dependent (response) variables. Lastly principal component analyses ( $\mathrm{PCoA}$ ) was used to test the effect of sites climate variables (temperature and precipitations) and treatments on species abundances, where treatments and climate variables were considered as main components and species abundances as variables. The method was replicated again using separately temperatures and precipitations as main components. All data analyses were made in PAST 4.02. Analyses were also made in PAST 4.02.

\section{Results}

Altogether more than 400,000 individuals of I. typographus and more than 600,000 individuals of $P$. chalcographus were captured and used for analyses. This means that in unmanaged forests site A the I. typographus abundance varied between 10.1 (early spring) and 849.7, (summer), in site B between 2.3 and 2237.3, while in site $C$ between 2.2 and 4565.6 during the assessment period. In managed forests, this variation was between 9 and 598.2 in site A, 1.8 ad 5733.8 in site B and between 3.5 and 11,667.5 in site C.

The abundance of $P$. chalcographus wearied in unmanaged forests between 12.1 and 6172.8 in site A, between 5 and 12,695.8 in site B and between 6.8 and 15,804.5 in site C. The species variation in managed forests was 7 to $46,386.2$ in site A, 3 to 7012.3 in site B and 6.3 to $19,831.7$ in site $C$ during the assessment period.

High abundance of both species were detected in all years of the investigation, both following 'unmanaged forests' (control) and 'managed forests' (treatment). While in 2011 the abundance of I. typographus was significantly higher in site C, its abundance increased in 2012, and high abundance in site B, under managed forests were also detected. Further increase in 2013 were observed also in site A, both in the unmanaged and managed forests (Figure 3A-C). Similar trends at P. chalcographus was detected, with higher abundance in 2011 on site B managed forests, in 2012 on site B unmanaged forests, and significantly higher abundances on site $C$ managed forests in 2013 (Figure 3D-F). By comparing all the data together, significantly higher abundances on site B unmanaged forests for I. typographus and site $\mathrm{C}$ managed forests were detected; however, other differences in mean abundances can be detected (Table S2, supplementary online materials).

Heat map analyses also revealed that the abundance of I. typographus in 2011 was concentrated at site $\mathrm{C}$, mostly during the spring flying period; this concentration, however, expanded in 2012 and in 2013, higher abundance developing also at sites B and A as well. Low abundance was observed in each year on site A, under managed forests (Figure $4 \mathrm{~A}-\mathrm{C}$ ). A rather different trend for P. chalcographus was detected, but only in 2011, when higher abundances were observed during the summer flying period (Figure 4D), while the expansion of high abundance in 2012 and 2013 were also detected, although at lower density in site A under managed forests (Figure 4E,F). Additional analyses on beetles flight dynamics (Supplementary online materials, Figure S1), revealed high synchronization between the two species, but also differences between sites and years were detected. 

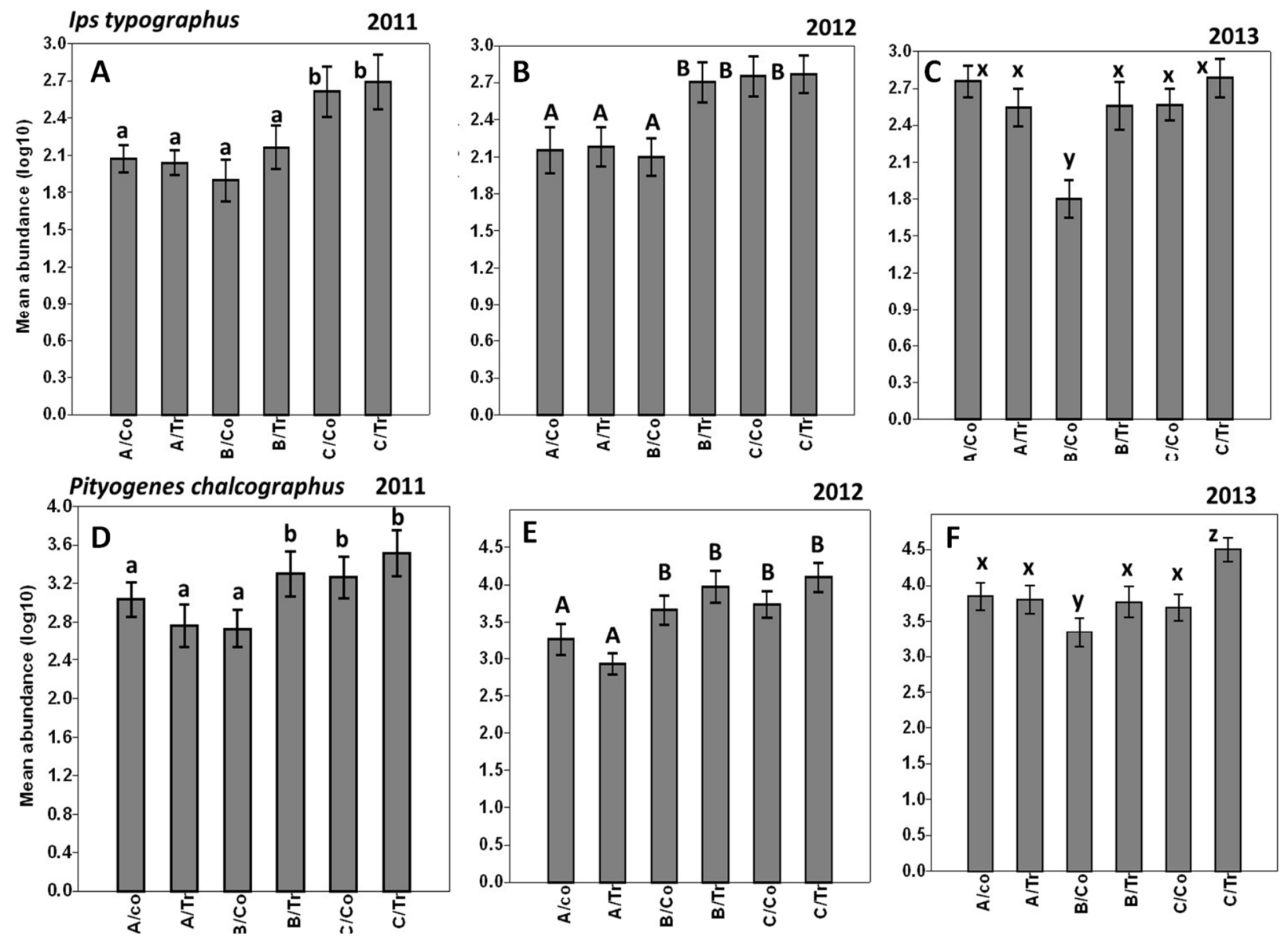

Figure 3. Mean abundances of I. typographus (A-C) and P. chalcographus (D-F), compared between sites and treatments using one-way ANOVA followed by Tukey HSD tests. Each year was considered separately. Different letters represents statistically significant differences $(p<0.05)$ according to the Tukey's multiple comparison test. Co = control (non-intervention zone), $\mathrm{Tr}=$ treatment (intervention zone). Differences in letters ( $\mathrm{a}, \mathrm{A}$ or $\mathrm{X}$ ) are used to mark significances inside the years and species.

General linear modelling (GLM) revealed that the effect of environmental variables (forest mean age, forest density, altitude and slope) on I. typographus density were only significant under treatment sites, and only forest age has significantly negative effect on density in 2011 and 2012. The abundance of $P$. chalcographus was positively influenced by altitude in 2012 and negatively influenced by the forest age and altitude in 2013 in control sites. Forest altitude had also negative effect on density under intervention strategy in 2012 and 2013 (Table 1).

Principal component analyses (PCoA) revealed that the greatest variation in densities were explained primarily by sites environmental variables (temperature and precipitations) in all years and flying periods and less influenced by non-intervention or intervention strategy systems. In most of the cases, climate variables together explained up to $80 \%$, while treatments only up to $30 \%$ (in 2011), but several times only up to $10 \%$ species densities (Figure 5). By considering separately temperature and precipitations, they explaining only up to $30-40 \%$ species densities, while no change in treatments effects were detected. 

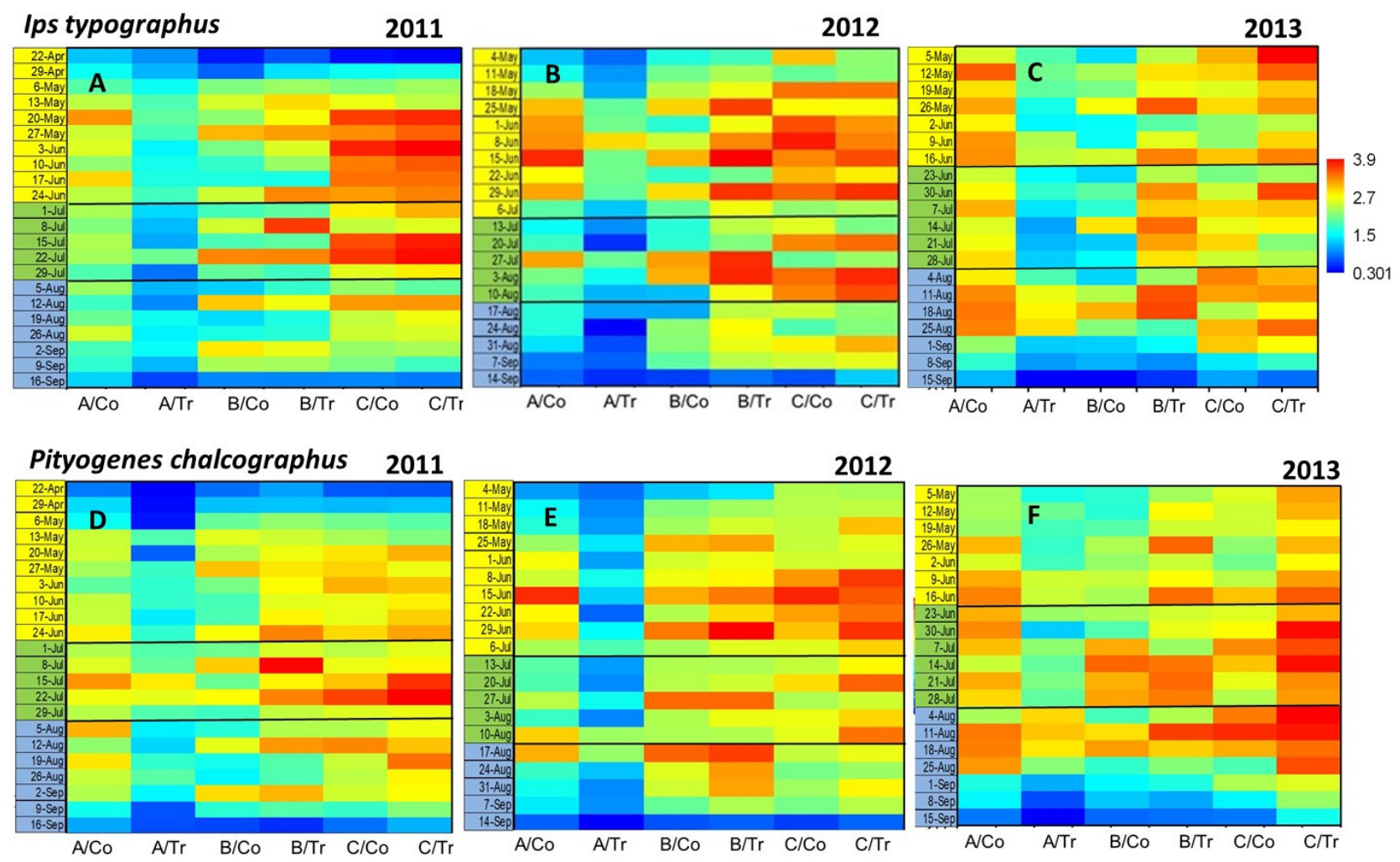

Figure 4. Heat-map matrices comparing abundances of I. typographus (A-C) and P. chalcographus (D-F), between sites, treatments and flying periods for each year and species. Blue colours represents low abundances, red colours high abundances. All data were log10 transformed and presented. Co-control (non-intervention zone), Tr-treatment (intervention zone).

Table 1. General linear model (GLM) using the effect of environmental variables on bark beetle density. Log10 transformed data were used for analyses. Arrows before value show the direction of main effects: $\uparrow$ indicates a positive relationship; $\downarrow$ a negative one. Significant values are in bold.

\begin{tabular}{|c|c|c|c|c|c|c|}
\hline \multirow[b]{3}{*}{ Indep. Var. } & \multicolumn{6}{|c|}{ I. typographus Density (Dep Variable) in Unmanaged Forests } \\
\hline & \multicolumn{2}{|c|}{2011} & \multicolumn{2}{|c|}{2012} & \multicolumn{2}{|c|}{2013} \\
\hline & Std.err. & $p$ & Std.err. & $p$ & Std.err. & $p$ \\
\hline Mean age (year) & 0.135 & 0.062 & 0.282 & 0.111 & 0.185 & 0.384 \\
\hline Forest dens. & 0.025 & 0.796 & 0.052 & 0.386 & 0.034 & 0.675 \\
\hline Altitude (m) & 0.041 & 0.124 & 0.086 & 0.516 & 0.056 & 0.715 \\
\hline \multirow[t]{2}{*}{ Slope } & 0.123 & 0.198 & 0.258 & 0.414 & 0.169 & 0.789 \\
\hline & \multicolumn{6}{|c|}{ I. typographus density (Dep variable) in managed forests } \\
\hline Mean age (year) & 3.557 & $0.054 \downarrow$ & 3.557 & $0.054 \downarrow$ & 0.619 & 0.669 \\
\hline Forest dens. & 0.617 & 0.374 & 0.617 & 0.374 & 0.347 & 0.620 \\
\hline Altitude (m) & 1.393 & 0.385 & 0.393 & 0.385 & 0.630 & 0.421 \\
\hline \multirow[t]{2}{*}{ Slope } & 1.084 & 0.613 & 1.084 & 0.613 & 0.594 & 0.892 \\
\hline & \multicolumn{6}{|c|}{ P. chalcographus density (Dep variable) in unmanaged forests } \\
\hline Mean age (year) & 0.101 & 0.152 & 0.075 & 0.074 & 0.068 & $0.034 \downarrow$ \\
\hline Forest dens. & 0.046 & 0.409 & 0.033 & 0.103 & 0.030 & 0.110 \\
\hline Altitude (m) & 0.033 & 0.270 & 0.024 & $0.015 \uparrow$ & 0.022 & $0.059 \downarrow$ \\
\hline \multirow[t]{2}{*}{ Slope } & 0.116 & 0.786 & 0.085 & 0.730 & 0.078 & 0.871 \\
\hline & \multicolumn{6}{|c|}{ P. chalcographus density (Dep variable) in managed forests } \\
\hline Mean age (year) & 1.674 & 0.220 & 2.196 & 0.102 & 1.729 & 0.720 \\
\hline Forest dens. & 0.393 & 0.142 & 0.708 & 0.509 & 0.305 & 0.065 \\
\hline Altitude (m) & 4.472 & $0.051 \downarrow$ & 4.411 & $0.005 \downarrow$ & 5.253 & 0.266 \\
\hline Slope & 1.802 & 0.746 & 2.589 & 0.508 & 1.615 & 0.900 \\
\hline
\end{tabular}



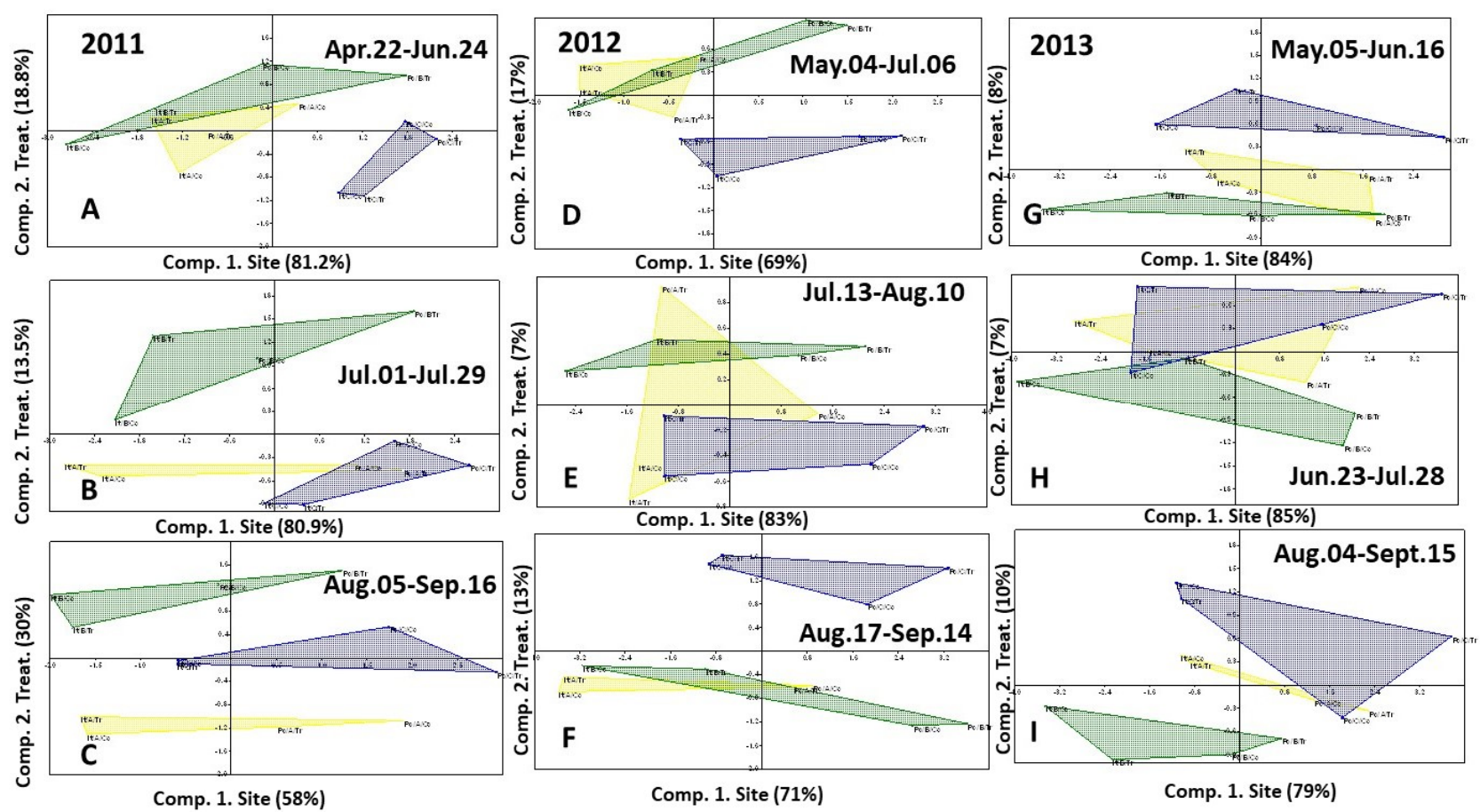

Figure 5. Principal component analyses (PCoA) to test the effect of site climate variables (temperature and precipitations) and treatments on species abundances, where climate variables and treatments were considered as the main components and species abundances as variables. Figures A-C represents year 2001, figures D-F 2002, and figures G-I year 2003. Yellow plains represent site $\mathbf{A}$, green site $\mathbf{B}$, and blue site $\mathbf{C}$. Differentiations inside years were made to have a proper comparison between site climate variables. As example year 1-29 July 2011 was similar or very closed in mean temperature and precipitation with 13 July-10 August 2012 and with 23 June-28 July 2013.

Principal component analyses $(\mathrm{PCOA})$ revealed that the greatest variation in densities were explained primarily by sites environmental variables (temperature and precipitations) in all years and flying periods and less influenced by non-intervention or intervention strategy systems. In most of the cases, climate variables together explained up to $80 \%$, while treatments only up to $30 \%$ (in 2011), but several times only up to $10 \%$ species densities (Figure 5). By considering separately temperature and precipitations, they explaining only up to $30-40 \%$ species densities, while no change in treatments effects were detected.

\section{Discussion}

High abundance of both species was detected in all years, both after non-intervention and intervention strategies. Increase in the abundance of I. typographus in 2011 was significant in site C; its abundance increased in 2012, and high abundance in site B, under managed forests were also detected. A further increase in 2013 was observed also at site A, both in unmanaged forests and managed forests. This can be partially explained because of the effect of environmental variables (forest mean age, forest density, altitude and slope) on I. typographus density were only significant under treatment sites, and only forest age has significantly negative effect on density in 2011 and 2012.

P. chalcographus showed a similar trend (Figure 4). The increase in its abundance in the unmanaged forests can be explained by the presence of scattered wind felled trees, which represent favorable places for oviposition and by the existence of standing trees attacked by beetles, and in the managed forests, by late removal of the mentioned categories of trees.

The high insects' density due to the high wood biomass probably influenced tree mortality, which further increased the insects' abundances until the end of 2013. This can be clearly observed when insect abundances are presented in the form of heat maps (Figure 4A-F), but also a synchronization in flight of the two species (Figure S3). 
Other research has reported another six bark beetle species inhabiting in the same area of the National Park Apuseni: I. amitinus (Eichhoff, 1872), I. acuminatus (Gyllenhal, 1827), P. chalcographus, Dryocoetes autographus (Ratzeburg, 1837), Hylurgops palliatus (Gyllenhal, 1813), and H. glabratus (Zetterstedt, 1828) [20].

The decision not to extract highly infected and dead trees by 2010 from unmanaged forests may also explain the high insect abundances. Some studies have also revealed that the reproduction of $P$. chalcographus increased significantly in wood residuals when these are collected near forest for a longer time [20-22]; however, damages to the nearest young and healthy trees through drying out were not significant [23].

Overall, general linear modelling (GLM) revealed that the effect of environmental variables (forest mean age, forest density, altitude and slope) on I. typographus density were only significant under the managed system, and only forest age has significantly negative effects on density in 2011 and 2012, but not in 2013. This further explains why the management strategies employed had increasing effect on insect abundance and this was followed by higher levels of captures in 2012 and 2013. A more detailed field survey revealed that within the unmanaged forests in 2011-2013, the felled tree biomass and old tree densities favoured insect reproductions and thereby density increase that influenced the nearest regions too. Principal component analyses (PCoA) revealed however that the greatest variation in densities was explained primarily by site climate variables (temperature and precipitations) in all years and less influenced by management systems. In most of the cases examined, site explained up to $80 \%$, while management only up to $30 \%$ (in 2011), and on several occasions, only up to 10\% of recorded species' densities (Figure 5). Considering separately temperature and precipitations they explained only up to 30-40\% density variations of both species. This result seems to contradict our previous findings; however, if the management strategies are considered in the intervention zone (i.e., late extraction of felled wood biomass and noting of the wood residuals, which favorited mostly P. chalcographus developments), we conclude that site has generally a more accentuating effect than management strategies.

Earlier studies claim that the two species cause increasing tree mortality when occurring together. The effect of $P$. chalcographus alone on Picea abies produced $8 \%$ tree mortality, while together with I. typographus, damage increased significantly [24].

Effect of the multiannual change in temperature and precipitations has to be more considered in the future. Higher temperature in association with low precipitations also had a catalytic effect on both species abundance, as observed when annual flight periods are compared (Figure 4, Figure S1). While in both 2011 and 2012, three flight period per year can clearly be discerned, this is less obvious in 2013, whereupon a more continuous flight period was observed. Species started showing activity at $16.8-17^{\circ} \mathrm{C}$ until a temperature of $35.6^{\circ} \mathrm{C}$ was reached [25]. The effect of climate change on these species' activity are now more often detected, the result of increasing global temperatures in forests with decreasing precipitation (e.g., in the Carpathian Mountains during the last few years), effects that have had a deleterious effect on tree physiology, thereby increasing their susceptibility to these insects [26,27].

\section{Conclusions}

It can be concluded that even over a relatively short time period (three years), as here examined, the population of both bark beetle species studied expanded, with new uninfected habitats being infected both under unmanaged and managed regimes, mostly due to the management involved, but also as a consequence of climate change. No relevant differences in population densities between unmanaged and managed forests were detected, this underlines the question as to how forest management, even in protected areas, should be followed in light of the insidious effects of ongoing climate change. If such practices continue to be followed in the future, a mass-extinction of resinous forests, mainly composed by spruce in the Carpathian Mountains, is to be expected, primarily due to these two bark beetle species (and evidently other species occurrences which have yet to 
be investigated), even under the guise of so called 'management' systems, as currently practiced. New habitat conservation, wood-management protocols and legislation urgently need to be introduced and followed to prevent these predicted forest mass extinctions, which seemingly are already happening over a relatively small time period (less than a decade), as here highlighted. From the standpoint of Biological Pest Management involving natural biological control agents, i.e., predators, parasitoids and/or natural products (i.e., entomopathogenic fungal treatments with Metarhisium or Beauveria), to combat these economically serious bark beetle pests, such an approach is to be recommended, especially when wood residuals are collected near healthy trees [28].

Supplementary Materials: The following are available online at https:/ /www.mdpi.com/article/10 .3390/f12060760/s1, Figure S1: Flight dynamics in 2011, 2012 and 2013 Ips + Pityogenes, Table S1: Research sites and details, Table S2: Statistical analyses comparing insect densities between sites, treatments and years (ANOVA). Above diagonal are probability ( $\mathrm{p}$ ) values; significant values are in bold, below diagonal are $\mathrm{F}$ values.

Author Contributions: Conceptualization, C.G.F.; methodology, C.G.F.; software, A.B.; validation, C.G.F. and A.B.; formal analysis, C.G.F. and A.B.; investigation, C.G.F.; resources, C.G.F.; data curation, C.G.F. and A.B.; writing-original draft preparation, C.G.F. and A.B.; writing—review and editing, C.G.F. and A.B.; visualization, C.G.F. and A.B.; supervision, C.G.F. and A.B.; project administration, C.G.F.; funding acquisition, C.G.F. and A.B. All authors have read and agreed to the published version of the manuscript.

Funding: This research was funded by POSDRU/89/1.5/S/6237, co-financed by the European Social Fund, through Sectorial Operational Program for Human Resources Development 2007-2013.

Acknowledgments: We thank to the administration of Natural Park Apuseni for technical support and general permission to sample insects. This paper is published from the own funds of the Banat's University of Agricultural Sciences and Veterinary Medicine from Timisoara and Research Institute for Biosecurity and Bioengineering Timisoara.

Conflicts of Interest: The authors of this article have no financial or other conflict of interest to declare.

\section{References}

1. Grégoire, J.-C.; Evans, H.F. Damage and Control of Bawbilt Organisms an Overview. In Bark and Wood Boring Insects in Living Trees in Europe, a Synthesis; Lieutier, F., Day, K.R., Battisti, A., Grégoire, J.-C., Evans, H.F., Eds.; Springer: Dordrecht, The Netherlands, 2004; pp. 19-37. ISBN 978-1-4020-2241-8.

2. Christiansen, E.; Bakke, A. The Spruce Bark Beetle of Eurasia. In Dynamics of Forest Insect Populations: Patterns, Causes, Implications; Population Ecology; Berryman, A.A., Ed.; Springer: Boston, MA, USA, 1988; pp. 479-503. ISBN 978-1-4899-0789-9.

3. Hlásny, T.; Turčáni, M. Persisting Bark Beetle Outbreak Indicates the Unsustainability of Secondary Norway Spruce Forests: Case Study from Central Europe. Ann. For. Sci. 2013, 70, 481-491. [CrossRef]

4. Marini, L.; Lindelöw, Å.; Jönsson, A.M.; Wulff, S.; Schroeder, L.M. Population Dynamics of the Spruce Bark Beetle: A Long-Term Study. Oikos 2013, 122, 1768-1776. [CrossRef]

5. Wermelinger, B. Ecology and Management of the Spruce Bark Beetle Ips Typographus-A Review of Recent Research. For. Ecol. Manag. 2004, 202, 67-82. [CrossRef]

6. Avtzis, D.N.; Arthofer, W.; Stauffer, C.; Avtzis, N.; Wegensteiner, R. Pityogenes Chalcographus (Coleoptera, Scolytinae) at the Southernmost Borderline of Norway Spruce (Picea Abies) in Greece. Entomol. Hell. 2010, 19, 3-13. [CrossRef]

7. Pfeffer, A. Bark and Ambrosia Beetles from the Central and West Palaearctic Region (Coleoptera, Scolytidae, Platypodidae). Available online: https:/ /www.cabi.org/isc/abstract/19951115912 (accessed on 9 March 2021).

8. Bertheau, C.; Salle, A.; Roux-Morabito, G.; Garcia, J.; Certain, G.; Lieutier, F. Preference-Performance Relationship and Influence of Plant Relatedness on Host Use by Pityogenes Chalcographus L. Agric. For. Entomol. 2009, 11, 389-396. [CrossRef]

9. Bouget, C.; Duelli, P. The Effects of Windthrow on Forest Insect Communities: A Literature Review. Biol. Conserv. 2004, 118, 281-299. [CrossRef]

10. Schwerdtfeger, F. A Contribution to the Biology of Reproduction of the Bark-Beetle, Ips Chalcographus. Available online: https:/ / www.cabi.org/isc/abstract/19300500054 (accessed on 9 March 2021).

11. Christiansen, E.; Waring, R.H.; Berryman, A.A. Resistance of Conifers to Bark Beetle Attack: Searching for General Relationships. For. Ecol. Manag. 1987, 22, 89-106. [CrossRef]

12. Sauvard, D. General Biology of Bark Beetles. In Bark and Wood Boring Insects in Living Trees in Europe, a Synthesis; Lieutier, F., Day, K.R., Battisti, A., Grégoire, J.-C., Evans, H.F., Eds.; Springer: Dordrecht, The Netherlands, 2004; pp. 63-88. ISBN 978-1-4020-2241-8. 
13. Zahradník, P.; Zahradníková, M. The Relationships between Pityogenes Chalcographus and Nemosoma Elongatum in Clear-Cuts with Different Types of Management. Plant Prot. Sci. 2019, 56, 30-34. [CrossRef]

14. Grodzki, W. Entomofauna of Dying Young Spruces Picea Abies (L.) Karst. in the Area after Forest Decline in the Izerskie Mountains. Folia For. Pol. Ser. A 2009, 51, 161-170. [CrossRef]

15. Weslien, J. Monitoring Ips Typographus (L.) Populations and Forecasting Damage1. J. Appl. Entomol. 1992, 114, 338-340. [CrossRef]

16. Lindelöw, Å.; Schroeder, M. Spruce Bark Beetle, Ips Typographus (L.), in Sweden: Monitoring and Risk Assessment. J. For. Sci. 2001, 47, 40-42.

17. Zúbrik, M.; Raši, R.; Vakula, J.; Varínsky, J.; Nikolov, C.; Novotný, J. Bark Beetle (Ips Typographus L., Pityogenes Chalcographus L., Col.: Scolytidae) Pheromone Traps Spatial Distribution Optimisation in Central Slovakian Mountains. Lesn. Časopis For. J. 2008, 54, 235-248.

18. Simionescu, A.; Mihalache, G.; Mihalciuc, V.; Ciornei, C.; Chira, D.; Olenici, N.; Lupu, D.; Nețoiu, C.; Vlăduleasa, A.; Iliescu, M.; et al. Protectia Pădurilor; Mușatinii: Suceava, Romania, 2003.

19. Mezei, P.; Blaženec, M.; Grodzki, W.; Škvarenina, J.; Jakuš, R. Influence of Different Forest Protection Strategies on Spruce Tree Mortality during a Bark Beetle Outbreak. Ann. For. Sci. 2017, 74, 65. [CrossRef]

20. Fora, C.G.; Lauer, K.F.; Moatar, M.M.; Stanciu, S. The Evaluation of the Bark Beetles Populations on Spruce Logging Debris. Bull. Univ. Agric. Sci. Vet. Med. Cluj-Napoca. Hortic. 2015, 72, 350-355. [CrossRef]

21. Kacprzyk, M. Feeding Habits of Pityogenes Chalcographus (L.) (Coleoptera: Scolytinae) on Norway Spruce (Picea Abies) L. (Karst.) Logging Residues in Wind-Damaged Stands in Southern Poland. Int. J. Pest Manag. 2012, 58, 121-130. [CrossRef]

22. Maes, D.; Titeux, N.; Hortal, J.; Anselin, A.; Decleer, K.; De Knijf, G.; Fichefet, V.; Luoto, M. Predicted Insect Diversity Declines under Climate Change in an Already Impoverished Region. J. Insect Conserv. 2010, 14, 485-498. [CrossRef]

23. Hedgren, P.O.; Weslien, J.; Schroeder, L.M. Risk of Attack by the Bark Beetle Pityogenes Chalcographus (L.) on Living Trees Close to Colonized Felled Spruce Trees. Scand. J. For. Res. 2003, 18, 39-44. [CrossRef]

24. Hedgren, P.O. The Bark Beetle Pityogenes Chalcographus (L.) (Scolytidae) in Living Trees: Reproductive Success, Tree Mortality and Interaction with Ips Typographus. J. Appl. Entomol. 2004, 128, 161-166. [CrossRef]

25. Lobinger, G. Air Temperature as a Limiting Factor for Flight Activity of Two Species of Pine Bark Beetles, Ips Typographus L. and Pityogenes Chalcographus L. (Col., Scolytidae); Landesanstalt fuer Wald und Forstwirtschaft: Freising, Germany, 1994.

26. Boyer, J.S. Biochemical and Biophysical Aspects of Water Deficits and the Predisposition to Disease. Annu. Rev. Phytopathol. 1995, 33, 251-274. [CrossRef] [PubMed]

27. Kalkstein, L.S. Effects of Climatic Stress Upon Outbreaks of the Southern Pine Beetle 12. Environ. Entomol. 1976, 5, 653-658. [CrossRef]

28. Fora, C.G.; Banu, C.; Chisăliţă, I.; Moatăr, M.; Oltean, I. Parasitoids and Parasitoids and Predators of Ips Typographus (L.) in Unmanaged and Managed Spruce Forests in Natural Park Apuseni, Romania. Not. Bot. Horti Agrobot. 2014, 42. [CrossRef] 